\title{
Functional impairment after treatment with pectoral muscle flaps because of deep sternal wound infection
}

Jenny Eriksson, Inger Huljebrant, Hans Nettelblad and Rolf Svedjeholm

\section{Linköping University Post Print}

N.B.: When citing this work, cite the original article.

Original Publication:

Jenny Eriksson, Inger Huljebrant, Hans Nettelblad and Rolf Svedjeholm, Functional impairment after treatment with pectoral muscle flaps because of deep sternal wound infection, 2011, SCANDINAVIAN CARDIOVASCULAR JOURNAL, (45), 3, 174-180.

http://dx.doi.org/10.3109/14017431.2011.563318

Copyright: Informa Healthcare http://informahealthcare.com/

Postprint available at: Linköping University Electronic Press http://urn.kb.se/resolve?urn=urn:nbn:se:liu:diva-68778 
FUNCTIONAL IMPAIRMENT AFTER TREATMENT WITH PECTORAL MUSCLE FLAPS BECAUSE OF DEEP STERNAL WOUND INFECTION

Jenny Eriksson ${ }^{3}$, Inger Huljebrant ${ }^{1}$, Hans Nettelblad ${ }^{2}$, Rolf Svedjeholm ${ }^{1}$. Dept of

Cardiothoracic Surgery ${ }^{1}$, Dept of Plastic Surgery ${ }^{2}$ and Medical School ${ }^{3}$, University Hospital, Linköping, Sweden.

Short title: Functional impairment after pectoral muscle flaps

Address reprint requests to: Prof. Rolf Svedjeholm. Dept. of Cardiothoracic Surgery,

University Hospital, SE-581 85 Linköping, Sweden. Tel.: + 46101030000 Fax: + 461310

0246

E-mail: rolf.svedjeholm@lio.se 


\section{ABSTRACT}

Objective: Pectoral muscle flaps (PMF) are effective in terminating protracted sternal wound infections (SWI) but long-term outcome remains uncertain. Therefore, the aim of this study was to evaluate long-term outcome in patients treated with PMF.

Design: 34 out of 263 patients revised because of deep SWI from 1991-2005 were treated with PMF. Of the 21 patients alive, 11 had left-sided, 2 right-sided and 8 bilateral procedures. Sternal debridement without closure of the sternum was done in 17 patients. 19/21 patients responded to a questionnaire.

Results: At follow-up on average 5.9 years (range 1.9-14.8 years) after surgery 63\% (12/19) experienced unstable chest. Two-thirds (12/18) reported problems carrying a grocery bag and $37 \%(7 / 19)$ had problems taking on a coat. Reduction of power and mobility was more common in the right arm and shoulder even in patients with left-sided PMF. 32\% (6/19) would have preferred alternative treatment if possible to avoid sternal instability even if healing had been substantially delayed.

Conclusions: Surgery with PMF and sternal debridement was associated with long-term disability, which appeared to be significant in one third of the patients. The function of the right arm and shoulder was affected more often despite the majority of procedures being leftsided suggesting that loss of skeletal continuity of the chest wall is more disabling than loss of pectoral muscle function.

Key words: cardiac surgery, long-term outcome, pectoral muscle flaps, postoperative complications, sternal wound infection 


\section{INTRODUCTION}

Deep sternal wound infections remain a major cause of morbidity and mortality after cardiac surgery and are costly for the health care system(1-6). Sternal wound infections also imply a considerable psychological burden for the patient(7). The incidence of sternal infection after sternotomy has been reported to vary between $0.25-9 \%(3,6,8-13)$. Post-discharge surveillance up to 3 months appears essential for reliable assessment of the true incidence of sternal wound infections $(9,14)$.

Until the 1980s the standard treatment of sternal wound infections was debridement and open granulation with secondary closure or closed catheter irrigation, but failure of treatment was common with mortality rates as high as $37.5 \%$ (15). The use of pectoral muscle flaps to treat severe and life-threatening sternal wound infections was introduced by Jurkiewicz et al in 1980 (16). Delaying closure of the wound until systemic signs of infection have subsided and the wound has healthy granulation tissue led to a significant decrease in complications related to muscle flap closure(17). Over the last years vacuum-assisted closure (VAC) has been used to accelerate this process with successful results facilitating both primary closure and closure with muscle flaps $(18,19)$.

Many reports show that vigorous sternal debridement and the use of muscle flaps are effective in terminating infections(20-22). Short-term studies assessing functional implications suggest potential long-term consequences for the patients(23, 24). However, available reports on the long-term consequences for patients treated with pectoral muscle flaps are few and conflicting(25-27). As it was our impression that the use of pectoral muscle flaps had increased at our institution we wanted to assess the use of pectoral muscle flaps and to evaluate the long-term outcome in these patients. 


\section{MATERIAL AND METHODS}

\section{Patients}

The University Hospital in Linköping is the only referral center in the southeast region of Sweden, serving a population of approximately one million. By examining our operation register we found a total of 263 patients who underwent surgical revision due to deep sternal wound infection between January 1991 and September 2005.

Of the 263 patient, 34 patients were treated with unilateral or bilateral pectoral muscle advancement flaps. 21 of these patients were alive in September 2006. Eleven of the patients had a left-sided procedure, 2 a right sided procedure and 8 had bilateral procedures. 19/ 21 patients responded to a questionnaire. The questionnaires were followed up by telephone contact when complementary information was needed. In spite of this, minor variations in the response rate to different questions remain explaining variations in the numbers and percentages presented. 17 patients responded to a complementary questionnaire assessing whether the patients were right- or left-handed. The average follow-up time was 5.6 \pm 3.3 (range 1.9-14.8) years after the original surgery.

Demographic and clinical data relevant to wound healing were retrieved from a database and from the patients' medical records. The study was performed according to the Helsinki Declaration of Human Rights and ethical approval waived by the Regional Ethical Review Board in Linköping according to the update of the Ethical Review Act (2003:460). 


\section{Questionnaire}

None of the standardized "Quality of Life forms" was found particularly useful in order to address the specific problems of pectoral muscle flap surgery. Hence, the query was based on consultation with our physiotherapists and the limited data on short term outcome available in the literature(24). The patients were asked to answer a questionnaire with 34 questions assessing sternal stability, cosmetic satisfaction, pain and ability to open a door, carry a grocery bag and to put on a coat. Patients were requested to grade disability into four grades: No disability, mild disability, significantly disabled but can manage by myself, severely disabled and in need of assistance. The questionnaire also assessed the role of postoperative chest problems in relation to other limiting comorbidities, patients overall satisfaction with the surgery and postoperative care, whether the postoperative complications made them regret the surgery and whether they would have preferred an alternative treatment even if it would have delayed healing by up to 3 months.

\section{Operative Technique}

The pectoral muscle flaps were with few exceptions dissected out by plastic surgeons according to a modified standard technique. The modification allowed harvest of enough muscular surface to cover the sternal defect by the left pectoral muscle in most cases. The left pectoral was elevated first and planned to be pedicled on the thoracoacromial vessels as the left side is unsafe to use on parasternal perforators if the left internal thoracic artery has been harvested.

Dissection was first conducted on the superficial side of the muscle, separating skin and subcutaneous tissue from the muscle. The endpoint of this dissection was the diagonal lateral border of the muscle, which was dissected caudally until the abdominal rectus was reached. A few centimetres of the rectus above the costal margin was included in the flap, which after the 
caudal transection was dissected free along the sternal border. The muscle was "rolled" cranially and the thoracoacromial vessels identified and followed on the deep side. The muscular origin on the clavicle was transected taking care that only the muscle origin on the anterior surface of the clavicle was severed, leaving the posteriorly located fibrofatty tissues. Transection was carried all the way laterally. Thereafter, the thick muscular convergence towards humerus was transacted allowing the flap to be pulled forward. By using a slightly rotating pull, the flap was able to reach the entire vertical length of the sternal cavity where it was sutured into place with resorbable sutures. If the left pectoral muscle did not suffice, the right flap was elevated, either antegrade or retrograde. The undermined skin flaps on both sides were closed in the midline.

\section{Statistical Analysis}

SPSS 14.0 (SPSS Inc, Chicago, IL) was used for descriptive statistical analyses. Cumulative long-term survival was assessed with Kaplan-Meier analysis. The results are presented as numbers, percentages or mean \pm standard deviation unless otherwise stated.

\section{RESULTS}

12125 surgical operations with cardiopulmonary bypass were performed at our institution over the time period studied, $263(2.2 \%)$ patients developed a deep sternal wound infection that was treated with surgical revision.

Over the time period 1991-2000,9.1\% of the patients with a deep sternal wound infection that required surgical revision ended up with pectoral muscle flaps at our institution. Between 2001 and 2005 the corresponding figure was 17.6\%. The use of omental flaps decreased over the same period of time (Figure 1). 
Overall $34(12.9 \%)$ of these patient ended up with pectoral muscle flaps. None of the patients died within 30 days from the primary procedure and Kaplan-Meier cumulative 5-year survival was $75.0 \%$.

Twenty-one of the patients were alive at follow-up on average 5.6 \pm 3.4 years after the pectoral muscle flap procedure. In one patient a stable sternum was covered by a pectoral muscle flap because of recurrent osteitis and in another patient partial stability of sternum was found. Furthermore, attempts to stabilize the sternum with PDS-suture (size 1 and 0 ) during surgery were made on 2 patients of whom one stated that the chest was stable in the questionnaire.

The demographic characteristics of the 21 patients included in this study are presented in table 1 and table 2 . All but four patients had undergone coronary artery bypass grafting with a concomitant valve procedure in two patients.

The most common pathogenic agents found among these 21 patients were Coagulasenegative staphylococci (13/21) and Staphylococcus Aureus (4/21). Escherichia Coli (1/21), Proteus Mirabilis (1/21), Enterococcus Faecalis (1/21) and Klebsiella Pneumonia (1/21) were found in the remaining cases.

\section{Sternal stability and functional result}

$68 \%(13 / 19)$ reported sensation of a clicking sternum and $63 \%(12 / 19)$ of the patients perceived that their chest was unstable. $75 \%(9 / 12)$ of the patients that reported unstable chest described this disability as mild and 25\% (3/12) reported it to be of a moderate degree. 
Although no one reported it to be of a severe degree 37\% (7/19) reported that they felt limited in their daily life to some extent because of unstable chest.

All patients who responded regarding the dominant hand were right-handed (17/17). The prevalence of self assessed functional disability in the upper extremities related to left-sided, right-sided and bilateral flaps are shown in figure 2 .

Problems from the right side were more common although 90\% (19/21) of the pectoral muscle flaps involved either left side or bilateral flaps whereas right sided or bilateral flaps were used in $48 \%(9 / 19)$ of the cases. $63 \%(10 / 16)$ of the patients experienced a reduction of power of the right arm and 47\% (8/17) a reduction of power of the left arm (Figure 2).

$47 \%(8 / 17)$ of the patients stated that their mobility of the right shoulder was reduced and $39 \%(7 / 18)$ that the mobility of left shoulder was reduced.

Regarding questions on the impact of daily life $67 \%$ (12/18) of the patients reported that they had problems carrying a grocery bag. $28 \%(5 / 18)$ required assistance and another $11 \%(2 / 18)$ reported significant difficulty although they managed without assistance.

$37 \%(7 / 19)$ experienced problems putting on a coat and 16\% (3/19) reported significant difficulties. No one required assistance.

$22 \%(4 / 18)$ had problems opening a door and $11 \%(2 / 18)$ reported significant difficulties. No one required assistance.

\section{Dyspnea}


$89 \%(16 / 18)$ of the patients were bothered by dyspnea prior to the original cardiac surgery, $75 \%(12 / 16)$ stated that they were less bothered at follow-up whereas $18 \%(3 / 17)$ expressed more problem with dyspnea at follow-up.

\section{Pain}

Overall $83 \%(15 / 18)$ of the patients stated that they experienced chest pain and $37 \%(7 / 19)$ reported that they were limited in their daily life because of this. Chest pain was initiated by movements of the chest in $40 \%(6 / 15)$ and by physical effort in $60 \%(9 / 15)$.

Of the patients that reported pain $78 \%(12 / 15)$ had it only infrequently and $60 \%(9 / 15)$ never used analgetic drugs. $20 \%$ (3/15) of the patients used analgetic drugs more than once weekly. Of the patients that reported pain 2 out of 15 regarded it to be angina pectoris and one of them reported complete pain relief by sublingual nitroglycerine.

\section{Cosmetic result}

$72 \%(13 / 18)$ of the patients reported that they were satisfied with the cosmetic results after the pectoral muscle flap procedure, $17 \%(3 / 18)$ were not completely satisfied and $11 \%(2 / 18)$ were dissatisfied.

\section{Overall satisfaction and the role of comorbidities}

At follow-up the mean age was $68 \pm 12$ years. Apart from the limitations reported above the patients also expressed limitations due to other causes presented in table 2. However, onethird (5/15) of the patients were mainly limited by postoperative chest problems and $44 \%$ (7/16) reported that they had ceased with recreational activities because of these problems. Although, 68\% (13/19) expressed overall satisfaction with the original surgical procedure and 
postoperative care $32 \%$ (6/19) would have preferred alternative treatment if possible even if healing of the wound infection had been delayed up to three months (table 2). None of the patients regretted undergoing cardiac surgery, despite their chest problems.

\section{COMMENT}

Overall problems with unstable chest, reduced mobility and power of the shoulder, and pain were common at long-term follow-up in our study. Although most patients reported their discomfort as mild it is noteworthy that the problems affected activities of daily life such as carrying a grocery bag in two thirds or taking on a coat in approximately one third of the patients. This also corresponded to overall satisfaction with the original procedure with the majority being satisfied but almost one third that would have preferred an alternative treatment even it would have prolonged the healing of the wound up to three months.

Our impression that the use of pectoral muscle flaps had increased was confirmed and they were used in $18 \%$ during the period 2001-2005. However, this appeared to be explained by a reduced use of omental flaps and thus not by a true increase in the use of flaps in general (figure 1). There is little data in the literature regarding the need for flap procedures in association with sternal wound infections. Klesius et al (23) reported a $19 \%$ incidence in patients with deep sternal wound infections, which is on level with our results despite markedly different bacteriological findings. The dominating pathogens in our study were Coagulase-negative staphylococci, which is in accordance with other studies $(6,9,11)$.

In contrast to previous studies, the majority of the patients in our study had problems with unstable chest and a clicking sternum. Ringelman et al (27) and Yuen et al (26) reported that 
$42.5 \%$ and $45 \%$ respectively perceived an unstable chest compared to $63.2 \%$ in our study. Most of our patients also reported a reduction of power and mobility of the arm and shoulder at either one or both sides (figure 2). Interestingly, the patients with left-sided flaps, either unilateral or bilateral, reported reduction of power and mobility more frequently on the right side. This might partly be explained by the fact that all patients that responded regarding favored hand were right-handed. Patients with bilateral flaps reported less problems on both sides than the patients with left-sided flaps. Only two patients had unilateral right-sided flaps and both of them reported reduced power of the right arm and one of them decreased mobility of the right shoulder. None of them had problems from the left side. By and large these findings suggest that loss of sternal stability and skeletal continuity of the chest wall is more disabling than loss of pectoral muscle function. Efforts to achieve a stable chest should thus have priority in the treatment of sternal infections.

A high success rate has been reported using VAC treatment as a single-line therapy followed by rewiring without the use of soft tissue flaps(4). Encouraging short-term results have also been reported combining bilateral pectoral muscle flaps with early surgical debridement and sternal closure employing rigid fixation principles(21). Sternal debridement and use of pectoral muscle flaps without sternal fixation should be considered a bail out procedure for life-threatening infections or protracted infections that cannot be terminated by a more conservative approach.

Ringelman et al (27), Yuen et al (26), and Francel et al (25) found a substantially lower prevalence of arm or shoulder weakness (41\%, 25\% and $20 \%$ respectively). Some of the discrepancy might be explained by the way questions were posed. In our study the patients were asked about reduced power and it is conceivable that a lesser proportion would have 
reported weakness than reduced power, as the majority of patients described their symptoms as mild.

The proportion of patients that reported pain was larger in our study $(83 \%)$ compared to that found by Yuen et al (26) and Ringelman et al (27) (43\% and 51\% respectively). However, the discomfort caused by pain in our patients appeared mild as $78 \%$ of the patients with pain only had it infrequently and $60 \%$ of them never used analgetic drugs.

The impact of pectoral muscle flaps on pulmonary function was not objectively assessed in our study but has been investigated previously. Cohen et al (28) compared the pulmonary function prior to and after reconstruction with pectoralis major and rectus abdominis flaps and found that the objective pulmonary function was significantly improved after reconstruction with muscle flaps, preferably pectoral muscle flaps.

Cosmetic problems appeared to be of lesser magnitude for the patients in our study with only $27.8 \%$ expressing dissatisfaction with the cosmetic result. In contrast, cosmetic problems appeared to overshadow problems from the shoulder and arm in the study by Yuen et al (26) who reported that $56 \%$ of the patients complained about noticeable and bothersome chest wall contour irregularity. The cosmetic result may vary depending on how it is assessed and by the surgical technique employed. Our patients were not examined by us and it is appreciated that individual perception, particularly of elderly patients, and findings on examination may differ. Ringelman et al (27) found abnormal contour on examination in $85 \%$ of the patients.

The study included all patients undergoing pectoral muscle flap procedures within an area of one million inhabitants and, hence, no referral selection bias should be present. In the absence 
of preoperative data we believe that functional testing would have added little and furthermore the patients' perception of the situation is what matters for the patient.

Our conclusion is that although sternal debridement combined with pectoral muscle advancement flap can be life-saving or terminate protracted sternal wound infections, this method should be used on strict indications given that one third of the patients have significant long-term disability. The finding that function of the right arm and shoulder was affected more often despite the majority of procedures being left-sided suggests that loss of skeletal continuity of the chest wall may be more disabling than loss of pectoral muscle function.

ACKNOWLEDGEMENT: The authors are indebted to Anette Brostedt, physiotherapist at the Dept of Cardiothoracic Surgery, Linköping University Hospital for professional advice when compiling the questionnaire. 


\section{TABLES AND FIGURES}

Table 1. Demographic characteristics in association with the original surgical procedure of the 21 patients with pectoral muscle flaps who were alive at follow-up.

Variables related to the original procedure

\begin{tabular}{|c|c|c|}
\hline Age (y) & \multicolumn{2}{|c|}{$62 \pm 12$} \\
\hline \multicolumn{3}{|l|}{ Sex } \\
\hline Male & $67 \%$ & $14 / 21$ \\
\hline Female & $33 \%$ & $7 / 21$ \\
\hline BMI & \multicolumn{2}{|c|}{$28.8 \pm 3.8$} \\
\hline Obesity (BMI $\geq 30)$ & $35 \%$ & $7 / 20$ \\
\hline Diabetes Mellitus & $55 \%$ & $11 / 20$ \\
\hline Chronic obstructive pulmonary disease & $20 \%$ & $4 / 20$ \\
\hline Hypertension & $55 \%$ & $11 / 20$ \\
\hline Peripheral vascular disease & $25 \%$ & $5 / 20$ \\
\hline NYHA (III-IV) & $88 \%$ & $15 / 17$ \\
\hline Urgent /Emergent surgery & $52 \%$ & $11 / 21$ \\
\hline \multicolumn{3}{|l|}{ Procedure } \\
\hline CABG & $71 \%$ & $15 / 21$ \\
\hline CABG + Valve & $10 \%$ & $2 / 21$ \\
\hline Valve & $14 \%$ & $3 / 21$ \\
\hline Thymectomy & $5 \%$ & $1 / 21$ \\
\hline \multicolumn{3}{|l|}{ Number of ITAs used (only CABG) } \\
\hline 1 & $94 \%$ & $16 / 17$ \\
\hline 2 & $6 \%$ & $1 / 17$ \\
\hline Cross-clamp time (minutes) & $59 \pm 3$ & \\
\hline ECC time (minutes) & $103=$ & \\
\hline Intensive Care Unit stay (days) & $9.1 \pm$ & \\
\hline
\end{tabular}


Table 2.

\begin{tabular}{|c|c|c|c|c|c|c|c|c|c|c|c|c|c|}
\hline Sex & $\begin{array}{l}\text { Age } \\
\text { at original } \\
\text { procedure }\end{array}$ & $\begin{array}{l}\text { Original } \\
\text { procedure }\end{array}$ & $\begin{array}{l}\text { Time } \\
\text { to } \\
\text { pectoral } \\
\text { muscle } \\
\text { flap } \\
\text { (days) }\end{array}$ & $\begin{array}{l}\text { Pectoral } \\
\text { muscle flap } \\
\text { Procedure }\end{array}$ & $\begin{array}{l}\text { Attempt } \\
\text { to } \\
\text { stabilize } \\
\text { sternum } \\
\text { or } \\
\text { Partially } \\
\text { stable } \\
\text { sternum }\end{array}$ & $\begin{array}{l}\text { Follow- } \\
\text { up since } \\
\text { Pectoral } \\
\text { Flap } \\
\text { Procedur } \\
\text { (years) }\end{array}$ & $\begin{array}{l}\text { Perception } \\
\text { of Unstable } \\
\text { chest }\end{array}$ & $\begin{array}{l}\text { Limited } \\
\text { by } \\
\text { Unstable } \\
\text { Chest }\end{array}$ & $\begin{array}{l}\text { Chest } \\
\text { pain }\end{array}$ & $\begin{array}{l}\text { Limited } \\
\text { by } \\
\text { Chest } \\
\text { pain }\end{array}$ & $\begin{array}{l}\text { Mainly } \\
\text { limited } \\
\text { by } \\
\text { Unstable } \\
\text { chest/ } \\
\text { Chest } \\
\text { pain }\end{array}$ & $\begin{array}{l}\text { Other } \\
\text { conditions } \\
\text { limiting } \\
\text { patient's } \\
\text { daily life }\end{array}$ & $\begin{array}{l}\text { Would } \\
\text { have } \\
\text { preferred } \\
\text { alternative } \\
\text { treatment }^{*}\end{array}$ \\
\hline M & 72 & CABGX3 & 84 & bilateral & & 14,5 & Yes & No & Yes & No & No & $\begin{array}{l}\text { Angina, } \\
\text { claudication }\end{array}$ & No \\
\hline M & 58 & CABGx6 & 19 & bilateral & $\begin{array}{l}\text { PDS } \\
\text { suture }\end{array}$ & 10,8 & Yes & No & Yes & No & No & $\begin{array}{l}\text { Liver } \\
\text { carcinoma }\end{array}$ & Yes \\
\hline M & 68 & CABGX3 & 31 & bilateral & $P S^{\star *}$ & 10,0 & No & No & Yes & Yes & & $\begin{array}{l}\text { Bilateral hip- } \\
\text { replacement } \\
\text {, poor } \\
\text { eyesight }\end{array}$ & No \\
\hline $\mathrm{F}$ & 64 & CABG $x 4$ & 28 & bilateral & $P S^{* *}$ & 9,3 & No & No & No & No & & & No \\
\hline $\mathrm{M}$ & 63 & CABG $x 4$ & 93 & left-sided & & 7,4 & Yes & Yes & Yes & Yes & Yes & & Yes \\
\hline M & 54 & CABGx5 & 27 & bilateral & & 7,1 & Yes & No & & No & No & $\begin{array}{l}\text { Ankylosing } \\
\text { spondylitis }\end{array}$ & No \\
\hline $\mathrm{F}$ & 72 & MV-plasty & 38 & left-sided & $\begin{array}{l}\text { PDS } \\
\text { suture }\end{array}$ & 6,9 & No & No & Yes & No & No & $\begin{array}{l}\text { Balance } \\
\text { problems }\end{array}$ & No \\
\hline$F(N R)$ & 76 & CABGx5 & 30 & left-sided & & 6,7 & & & & & & & \\
\hline M & 64 & CABGx4 & 54 & left-sided & & 5,4 & No & No & Yes & Yes & No & $\begin{array}{l}\text { COPD, } \\
\text { LLCP }^{* * *}\end{array}$ & No \\
\hline $\mathrm{M}$ & 58 & CABGX3 & 28 & left-sided & & 5,3 & Yes & Yes & Yes & Yes & No & & No \\
\hline$M$ & 39 & CABGx2 & 48 & left-sided & & 5,1 & Yes & Yes & Yes & No & Yes & & Yes \\
\hline M & 35 & Thymectomy & $\begin{array}{l}>6 \\
\text { years }\end{array}$ & $\begin{array}{l}\text { right- } \\
\text { sided }\end{array}$ & & 5,1 & Yes & No & Yes & Yes & & Back pain & Yes \\
\hline M & 55 & CABGx4 & 37 & bilateral & & 4,4 & Yes & Yes & Yes & Yes & & $\begin{array}{l}\text { Pain located } \\
\text { to the back } \\
\text { of the left } \\
\text { hand, } \\
\text { LLCP }^{* * *}\end{array}$ & No \\
\hline
\end{tabular}




\begin{tabular}{|c|c|c|c|c|c|c|c|c|c|c|c|c|}
\hline $\mathrm{F}$ & 67 & $\begin{array}{l}\text { CABGx2+AV } \\
R\end{array}$ & 30 & bilateral & 4,3 & Yes & No & No & No & No & $\begin{array}{l}\text { COPD, } \\
\text { arthralgia }\end{array}$ & No \\
\hline$M$ & 56 & CABGx5 & 44 & left-sided & 4,0 & No & No & No & No & No & $\begin{array}{l}\text { Ischemic leg } \\
\text { wound, joint } \\
\text { stiffness }\end{array}$ & No \\
\hline$M$ & 61 & CABGx5 & 121 & left-sided & 2,8 & Yes & Yes & Yes & No & No & $\begin{array}{l}\text { Arthrosis } \\
\text { (knee, feet) }\end{array}$ & Yes \\
\hline M & 66 & $\begin{array}{l}\text { CABG } x 1+A V \\
R\end{array}$ & 64 & left-sided & 2,8 & Yes & Yes & Yes & No & Yes & $\begin{array}{l}\text { Rheumatoid } \\
\text { arthritis, } \\
\text { LLCP }^{\star \star *}\end{array}$ & Yes \\
\hline $\mathrm{F}$ & 79 & AVR & 571 & bilateral & 2,0 & No & No & Yes & Yes & Yes & & No \\
\hline $\mathrm{M}(\mathrm{NR})$ & 45 & CABGx2 & 139 & left-sided & 1,8 & & & & & & & \\
\hline$F$ & 75 & MV-plasty & 30 & left-sided & 1,8 & Yes & Yes & Yes & No & Yes & $\begin{array}{l}\text { "Legs get } \\
\text { tired" }\end{array}$ & No \\
\hline $\mathrm{F}$ & 72 & CABG $x 4$ & 224 & $\begin{array}{l}\text { right- } \\
\text { sided }\end{array}$ & 1,5 & No & No & Yes & No & No & LLCP $^{* * *}$ & No \\
\hline
\end{tabular}




\section{LEGENDS}

\section{Table 1.}

Demographic and perioperative characteristics in association with the original surgical procedure of the 21 patients with pectoral muscle flaps who were alive at follow-up BMI = Body Mass Index; NYHA= New York Heart Association; CABG= Coronary Artery Bypass Grafting; ITA=Internal Thoracic Artery; ECC= Extracorporeal circulation.

\section{Table 2.}

Presentation of individual patients and main outcome with regard to original procedure, duration to and type of pectoral muscle flap procedure, attempt to stabilize sternum or pectoral muscle flap procedure performed in a patient with partially stable sternum (PS), duration of follow-up and limitations in relation to comorbidity. $\mathrm{M}=$ male, $\mathrm{F}=$ female, $(\mathrm{NR})=$ did not respond to questionaire. * Indicates patient who would have preferred alternative treatment if possible even if healing of the wound infection had been delayed up to three months. PS** $=$ sternum partially stable. Arthralgia refers to pain in joints not specified by the patients LLCP*** = lower limb circulatory problem not specified by the patient. COPD = chronic obstructive pulmonary disease.

\section{Figure 1.}

Distribution of procedures related to deep sternal wound infections $1991-2005$.

\section{Figure 2.}

Self assessed functional disability in the upper extremities with regard to reduction in power and active mobility of the shoulder. 


\section{REFERENCES}

1. El Oakley RM, Wright JE. Postoperative mediastinitis: classification and management. Ann Thorac Surg. 1996; 61:1030-6.

2. Friberg O, Dahlin LG, Levin LA, Magnusson A, Granfeldt H, Kallman J, et al. Cost effectiveness of local collagen-gentamicin as prophylaxis for sternal wound infections in different risk groups. Scand Cardiovasc J. 2006; 40:117-25.

3. Toumpoulis IK, Anagnostopoulos CE, Derose JJ, Jr., Swistel DG. The impact of deep sternal wound infection on long-term survival after coronary artery bypass grafting. Chest. 2005; $127: 464-71$

4. Mokhtari A, Sjogren J, Nilsson J, Gustafsson R, Malmsjo M, Ingemansson R. The cost of vacuum-assisted closure therapy in treatment of deep sternal wound infection. Scand Cardiovasc J. 2008; 42:85-9.

5. Risnes I, Abdelnoor M, Almdahl SM, Svennevig JL. Mediastinitis after coronary artery bypass grafting risk factors and long-term survival. Ann Thorac Surg. 1502; 89:1502-9.

6. Steingrimsson S, Gottfredsson M, Kristinsson KG, Gudbjartsson T. Deep sternal wound infections following open heart surgery in Iceland: a population-based study. Scand Cardiovasc J. 2008; 42:208-13.

7. Swenne CL, Skytt B, Lindholm C, Carlsson M. Patients' experiences of mediastinitis after coronary artery bypass graft procedure. Scand Cardiovasc J. 2007; 41:255-64.

8. Group TPMS. Risk factors for deep sternal wound infection after sternotomy: a prospective, multicenter study. J Thorac Cardiovasc Surg. 1996; 111:1200-7.

9. Jonkers D, Elenbaas T, Terporten P, Nieman F, Stobberingh E. Prevalence of 90-days postoperative wound infections after cardiac surgery. Eur J Cardiothorac Surg. 2003; 23:97102. 
10. Sharma M, Berriel-Cass D, Baran J, Jr. Sternal surgical-site infection following coronary artery bypass graft: prevalence, microbiology, and complications during a 42-month period. Infect Control Hosp Epidemiol. 2004; 25:468-71.

11. Wilson AP, Weavill C, Burridge J, Kelsey MC. The use of the wound scoring method 'ASEPSIS' in postoperative wound surveillance. J Hosp Infect. 1990; 16:297-309.

12. Stahle E, Tammelin A, Bergstrom R, Hambreus A, Nystrom SO, Hansson HE. Sternal wound complications--incidence, microbiology and risk factors. Eur J Cardiothorac Surg. 1997; 11:1146-53.

13. Gummert JF, Barten MJ, Hans C, Kluge M, Doll N, Walther T, et al. Mediastinitis and cardiac surgery--an updated risk factor analysis in 10,373 consecutive adult patients. Thorac Cardiovasc Surg. 2002; 50:87-91.

14. Friberg O, Svedjeholm R, Soderquist B, Granfeldt H, Vikerfors T, Kallman J. Local gentamicin reduces sternal wound infections after cardiac surgery: a randomized controlled trial. Ann Thorac Surg. 2005; 79:153-61.

15. Grossi EA, Culliford AT, Krieger KH, Kloth D, Press R, Baumann FG, et al. A survey of 77 major infectious complications of median sternotomy: a review of 7,949 consecutive operative procedures. Ann Thorac Surg. 1985; 40:214-23.

16. Jurkiewicz MJ, Bostwick J, 3rd, Hester TR, Bishop JB, Craver J. Infected median sternotomy wound. Successful treatment by muscle flaps. Ann Surg. 1980; 191:738-44.

17. Lindsey JT. A retrospective analysis of 48 infected sternal wound closures: delayed closure decreases wound complications. Plast Reconstr Surg. 2002; 109:1882-5.

18. Sjogren J, Malmsjo M, Gustafsson R, Ingemansson R. Poststernotomy mediastinitis: a review of conventional surgical treatments, vacuum-assisted closure therapy and presentation of the Lund University Hospital mediastinitis algorithm. Eur J Cardiothorac Surg. 2006; 30:898-905.

19. Immer FF, Durrer M, Muhlemann KS, Erni D, Gahl B, Carrel TP. Deep sternal wound infection after cardiac surgery: modality of treatment and outcome. Ann Thorac Surg. 2005; 80:957-61. 
20. Pairolero PC, Arnold PG, Harris JB. Long-term results of pectoralis major muscle transposition for infected sternotomy wounds. Ann Surg. 1991; 213:583-9.

21. El Gamel A, Yonan NA, Hassan R, Jones MT, Campbell CS, Deiraniya AK, et al. Treatment of mediastinitis: early modified Robicsek closure and pectoralis major advancement flaps. Ann Thorac Surg. 1998; 65:41-6.

22. Jones G, Jurkiewicz MJ, Bostwick J, Wood R, Bried JT, Culbertson J, et al. Management of the infected median sternotomy wound with muscle flaps. The Emory 20 -year experience. Ann Surg. 1997; 225:766-76.

23. Klesius AA, Dzemali O, Simon A, Kleine P, Abdel-Rahman U, Herzog C, et al. Successful treatment of deep sternal infections following open heart surgery by bilateral pectoralis major flaps. Eur J Cardiothorac Surg. 2004; 25:218-23.

24. Netscher DT, Eladoumikdachi F, McHugh PM, Thornby J, Soltero E. Sternal wound debridement and muscle flap reconstruction: functional implications. Ann Plast Surg. 2003; $51: 115-22$.

25. Francel TJ, Kouchoukos NT. A rational approach to wound difficulties after sternotomy: reconstruction and long-term results. Ann Thorac Surg. 2001; 72:1419-29.

26. Yuen JC, Zhou AT, Serafin D, Georgiade GS. Long-term sequelae following median sternotomy wound infection and flap reconstruction. Ann Plast Surg. 1995; 35:585-9.

27. Ringelman PR, Vander Kolk CA, Cameron D, Baumgartner WA, Manson PN. Long-term results of flap reconstruction in median sternotomy wound infections. Plast Reconstr Surg .1994; 93:1208-14.

28. Cohen M, Yaniv Y, Weiss J, Greif J, Gur E, Wertheym E, et al. Median sternotomy wound complication: the effect of reconstruction on lung function. Ann Plast Surg. 1997; 39:36-43. 


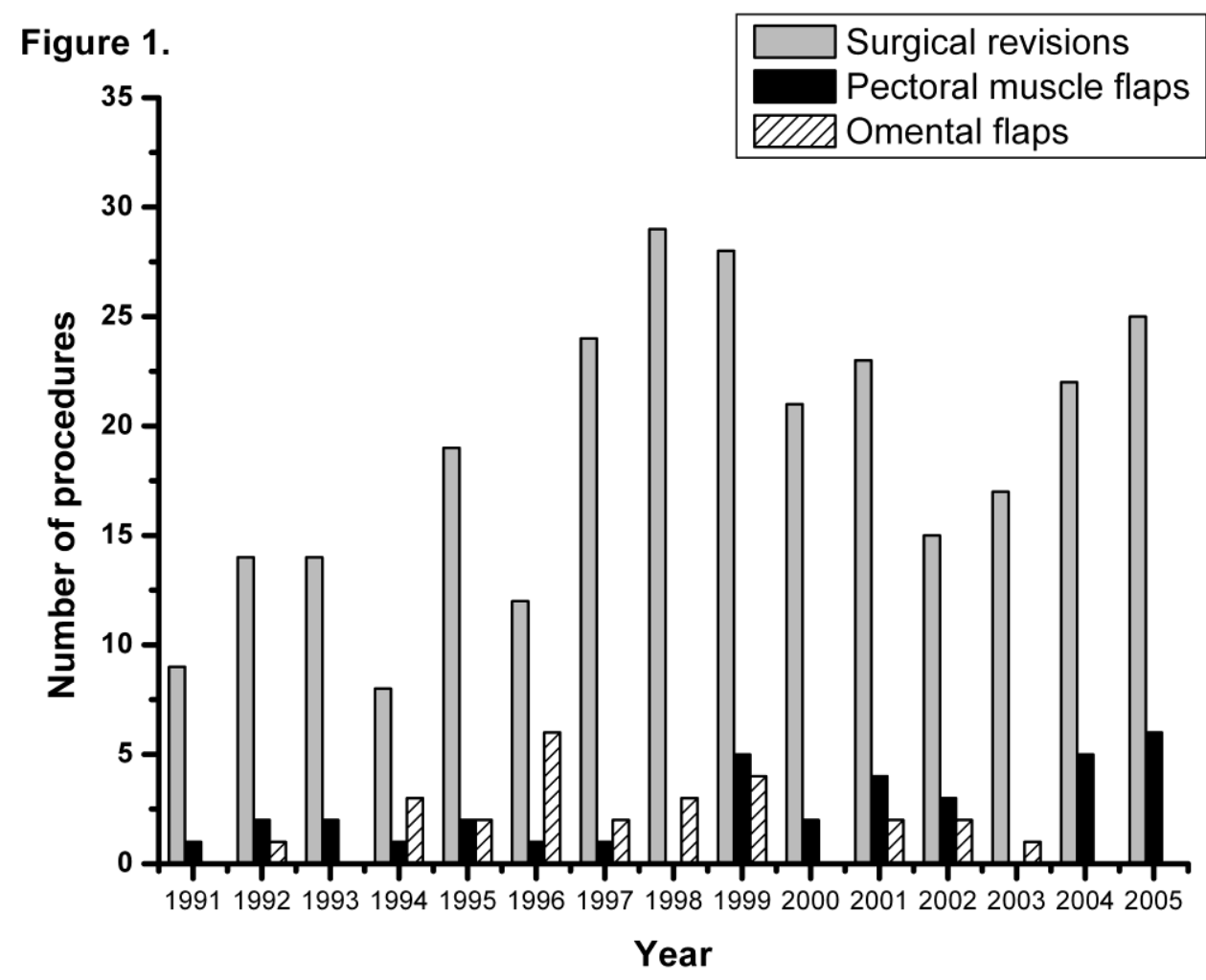


Figure 2.

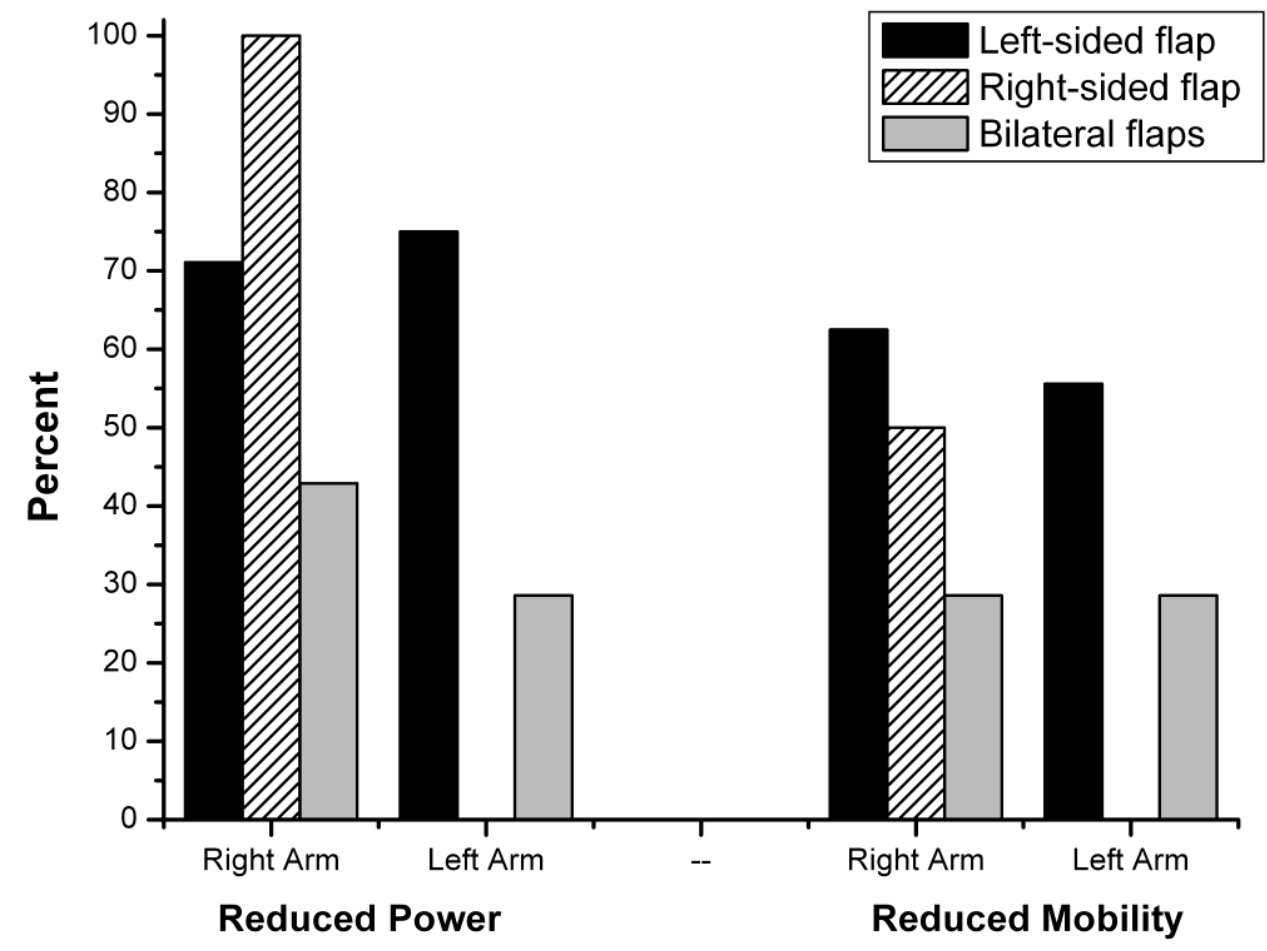

